\title{
Okul Öncesi Dönemde Sosyal Çevre Konusunda Uygulanan Proje Yaklaşımlı Eğitim
}

\section{Project Approach Education on Social Environment in Preschool Period}

\section{Duygu ÇETINGÖZ*}

$\ddot{O}_{z}:$ Bu çalışmanın amacı, okul öncesi eğitim döneminde proje yaklaşımlı eğitim uygulamasının çocukların sosyal çevreye yönelik bilgi düzeylerindeki değişimini incelemektir. Araştırmanın çalışma grubu 2014-2015 güz yarıyılında İzmir Küçükyalı Mesleki ve Teknik Anadolu Lisesi’nin uygulama sınıfında eğitim görmekte olan dört yaş grubundaki 6 çocuktan oluşmaktadır. Çalışma grubunun seçiminde ölçüt örnekleme kullanılmıştır. Ülkemizde proje yaklaşımlı eğitimin genellikle 5-6 yaş grubundaki çocuklarla çalışıldığ dört yaş grubunda çocuklarla yapılan yok denecek kadar az çalışma bulunduğu belirlenmiştir. $\mathrm{Bu}$ nedenle bu çalışmada önceden belirlenmiş ölçüt, proje yaklaşımının dört yaş grubundaki çocuklarla çalışılması olarak kabul edilmiştir. Araştırmanın yöntemi nitel araştırmadır. Nitel araştırma desenlerinden durum çalışması deseni kullanılmıştır. Bu çalışmada durum çalışmalarından "Öncesi-Sonrası Durum Çalışması" kullanılmıştır. Araştırmada veriler görüşme yöntemi ve çocukların çizdikleri resimler yoluyla toplanmıştır. Bulgularda çocukların görüşme verileri ana temalar-alt temalar halinde tablolaştırılmış ve ön-son değerlendirmeler şeklinde yorumlanmıştır. Benzer bir biçimde resimler de sosyal çevre kavramlarına yönelik ilk-son çizimler olarak değerlendirilmiştir. Her iki yolla elde edilen sonuçlarda proje yaklaşımının uygulanmasından sonra ana ve alt temalarda sosyal çevre kavramlarına yönelik artış olduğu belirlenmiştir.

Anahtar sözcükler: Okul Öncesi Eğitim, Proje Yaklaşımı, Sosyal Çevre, Dört Yaş Grubu

\begin{abstract}
The objective of this study is to examine the change in the level of children's knowledge about the social environment by applying project approach education in pre-school education period. Study group consisted of 6 children who attended the practice classroom of İzmir Küçükyalı Vocational and Technical Anatolian School during 2014-2015 Fall Semester. Criterion sampling technique was applied when choosing the work group. The Project Approach is usually applied to 5-6 year old children in Turkey and studies employing this approach to 4 year olds are very limited. Therefore the pre-determined criterion for this study is the usage of the Project Approach for four year old children. This is a case study, one of the qualitative research methods. This study employs pre-post case study method. Children were interviewed and the pictures they drew were investigated. The data collected from the children after the interviews were put into tables as themes and sub themes and commented as pre-post evaluations. Similarly, children's drawings were interpreted as pre-post evaluations and an increase regarding the concepts were identified.
\end{abstract}

Keywords: Pre-School Education, Project Approach, Social Environment, Four-Year-Olds

\footnotetext{
* Yrd. Doç. Dr, Dokuz Eylül Üniversitesi, Buca Eğitim Fakültesi, Temel Eğitim Bölümü, Okul Öncesi Eğitimi Anabilim Dal1, İzmir. duygucetingoz@ gmail.com

Bu makale 14-15 Nisan 2016 tarihinde 1. Uluslararası Kadın Çocuk Sağlığı ve Eğitimi Kongresi’nde sözlü bildiri olarak sunulmuştur.
} 


\section{Giriş}

Sosyal çevre insanın geniş çevre (grup, toplum) ve evrensel çevresi (ülke, dünya, uzay) ile etkileşim sürecine bağlı, bireyin toplumsallaşmasını sağlayan bir ortamdır. Bireyin bebek-anne ilişkisi ile başlayan sosyal çevresi, okul, iş gibi sosyal gruba ve topluma katılması ile giderek gelişir (Sabuncu et al. 1996). Okul öncesi dönemde çocuğun sosyal çevresine ilişkin bilgilerinin geliştirilmesi onun toplumsallaşma sürecine olumlu katkı sağlayacaktır. Ayrıca okul öncesi dönemde çocuğun sosyal çevresine öğrenmeye yönelik doğal ilgi ve isteği de bulunmaktadır. Bu konuda okul öncesi eğitim kapsamında çocuklara sistematik ve düzenli bir biçimde öğrenme ortamı sunmak daha nitelikli ve kalıcı öğrenmelerin gerçekleştirilmesini kolaylaştıracaktır. İçerik olarak sosyal bilgiler programı çocuğun sosyal çevresine yönelik kazanacağı bilgileri desteklemektedir. Çocuklar sosyal bilgiler programında yer alan coğrafya ve tarihle ilgili etkinlikler sayesinde; olayların ve yerlerin zamanla birbirlerini nasıl etkilediğini, insanların kendi çevrelerini geçmişin farklı dönemlerinde nasıl değiştirdiklerini ya da çevrelerinin onları nasıl değiştirdiğini anlarlar (Tuğrul \& Güler 2007).

Çocuklar öncelikle kendilerini sonra ailelerini daha sonra yakın çevrelerini ve son olarak genişleyen bir biçimde dünyayı öğrenirler (Taylor 1999). Sosyal bilgiler öğretimi sadece çocuğun bilişsel gelişimini değil aynı zamanda sosyal gelişimini de destekler. Deneyimlemiş oldukları bu sosyal bilgiler öğrenme süreci içerisinde kültürlere ait çeşitli kavramlarla da karşılaşmaktadırlar. Bu süreç içerisinde çocukların kültürel yeterlilik kazanmaları oldukça önemlidir. Kostelnik, Gregory, Soderman, Whiren (2012)'ye göre kültürel yeterlikte farklı kültürel kökenli kişilere saygı duyma, onlarla fikir alışverişinde bulunma, etkili iletişimde bulunma ve sosyal adaleti sağlama gibi davranışlar ve beceriler yer almaktadır. Kültürel yeterlilik çocuğun sosyal yeterlilik kazanmasında da temel unsurlarından biridir. Çocuğun sosyal gelişimi ile ilgili ekolojik sistem kuramını geliştiren Urie Bronfenbrenner ise insan gelişiminin birey ile onu kapsayan toplumsal, fiziksel ve kültürel çevre arasındaki karşılıklı etkileşimler yoluyla gerçekleştiğini ifade etmektedir (Bronfenbrenner \& Ceci 1994 akt. Ahioğlu-Lindberg 2012). Bronfenbrenner insan gelişiminde sistem teorisini geliştirmiştir. Sistem teorisinde hem çocuğun doğrudan üyesi olduğu ev, sokak, okul gibi bağlamları hem de kültür, gelenekler, değerler, kurallar gibi toplumsal ve tarihsel kökenleri olan sistemler yer almaktadır (Ahioğlu-Lindberg 2012). Bu bağlamda okul öncesi dönemde çocuğun sosyal bilgileri öğrenerek sosyal çevresine yönelik bilgiler kazanmasının çocuğun sosyal gelişimi üzerinde olumlu etkileri olduğu düşünülmektedir.

ABD'de okul öncesi dönemde sosyal bilgiler öğretim programının beş farklı alan (küresel eğitim, tarih, coğrafya, ekonomi ve güncel konuları) çatısı altında insan grupları ile ilgili bir içeriğe sahip olduğu görülmektedir (Mindes 2005 akt. Aktın 2014). Taylor (1999) okul öncesi dönemde sosyal bilgiler öğretiminin ekoloji, ekonomi, güncel olaylar, coğrafya, tarih, sosyoloji ile ilgili etkinlikleri kapsadığını belirtmektedir. Milli Eğitim Bakanlığı Okul Öncesi Eğitim Programında açık olarak ifade edilen tarih ve coğrafya konularının olduğu bir sosyal bilgiler çalışma alanı yoktur. Ancak okul öncesi eğitim programının içinde örtük olarak tarih ve coğrafya ile ilgili birçok amaç yer almaktadır (Tuğrul \& Güler 2007). Bu bağlamda çocuğun sosyal çevresini öğrenmesini kolaylaştıran coğrafya eğitiminin temel bileşenlerini; konum, yer, insançevre etkileşimi, hareket ve bölge oluştururken, tarih eğitiminin ise şimdi ve uzun zaman önce, çocukların kişisel tarihi, yakın çevre ve yaşadıkları toplum, dünyadaki farklı kültürlerdeki insanlar, bilim ve teknolojideki keşifler oluşturmaktadır (Hannibal, Vasiliev \& Lin 2002 akt. Tuğrul \& Güler 2007).

Tarih ve coğrafya çocukların yaşamlarını gözden geçirmelerini kendi yaşamları dışındaki farklı yaşamların da olduğunu anlamalarını sağlar. Çocuklar tarih ve coğrafya bilgileri sayesinde; 
- Diğerlerini/çevresindekileri keşfetmeyi,

- Farklı kültürleri öğrenmeyi,

- Farklı insanları tanımayı,

- Farklılıkları kabul etmeyi, saygı göstermeyi ve onlara değer vermeyi öğrenebilirler (Perry 2002).

Sosyal çevremizi daha kolay anlamamızı sağlayan coğrafya, yaşamımızda devamlı karşımıza çıkmaktadır. Çocuklar da coğrafyayla farkında olmadan erken yaşlarda karşılaşırlar. Yaşadıkları yerin özelliklerini öğrenmeye çalışan çocuklar evlerinin etrafinda gördükleri her şeyin konumunu çok küçük yaşlarda öğrenebilmektedirler. Parka giderken izledikleri yol, odalarındaki eşyaların yerleri, okullarının yeri ve sınıflarının düzeni, çocukların konum-yer ve harita bilgisinin temellerini oluşturmaktadır. (Kılıç, Güleç \& Genç 2014). Benzer bir biçimde çocuğun farklı bir şehirde yaşayan tanıdığından gelen kartpostal, farklı bir semtte oturan tanıdığının evinin adresini aramak, harita okumalarına yardımcı olmak, bir odanın ya da bir alanın planı üzerinde çalışmak, çocukların yaşadığı çevre hakkında bilgi sahibi olabilmesi için okulda, okul çevresine ve yaşadığı çevreye alan gezileri düzenleyerek burada binalar, yönler ve çevredeki alanlar hakkında bilgilenmelerini sağlamak vb. temel coğrafya kavramlarıyla ilgili günlük deneyimler ve etkinlikler arasında sayılabilir (Taylor 1999; Tuğrul \& Güler 2007). Coğrafyada kavramların doğru öğrenilmesi ve kalıcı bilgiler haline dönüştürülmesi, coğrafya öğrenme açısından oldukça önemlidir. Coğrafi kavramları öğrenirken ezberciliğin benimsenmesi ile öğrenciler öğrendiklerini bir süre sonra unutmaktadır (Akengin \& Süer 2011). Bu noktada çocukları ezbercilikten kurtarmak adına çocuklarla beraber alan gezileri düzenlemek ve aile katılımlı çalışmalar yapmak oldukça önemlidir. Özellikle aile ile beraber çocuğun itfaiye, hastane, postane gibi alanlara beraber gitmesi ve burada çalışan kişilerin görevleri ve insanlara nasıl yardımcı oldukları hakkında bilgi almaları keşfederek ve yaşayarak öğrenmelerini sağlayacaktır (Taylor 1999).

Bulunduğumuz andan öncesi, yani bir geçmiş olduğunun farkına varılmasıyla ilgili soruların cevaplarını veren tarih öğrenmede de (Tuğrul \& Güler 2007) hatırda tutma ve akıl süzgecinden geçirerek öğrenme önem taşımaktadır. Bu nedenle tarihsel düşünme becerilerinden kronolojik düşünme, tarihi kavrama, tarihi analiz etme ve yorumlama, tarihi araştırma becerisi edinme, tarihi olaylar hakkında karar verme (Tuğrul \& Güler 2007) çocuklara küçük yaşlarda kazandırılmaya başlanmalıdır. Sokakta yürürken ve taşıt içindeyken, çevredeki yerleşim yerlerine, sokak, cadde, apartman isimlerine ve numaralarına dikkati çekme, görsel sembollerin anlamlarını konuşma, tarihi binaları, eşyaları, yerleri vb. inceleme, çocuklarla belirli bir ülke, şehir, semt, mahalle vb. seçip, bu yerleri tanıtan projeler hazırlama, daha önce ne olmuş olabileceği ve değişimler hakkında konuşmak gibi etkinlikler (Taylor 1999; Tuğrul \& Güler 2007) tarih öğretimi kapsamında çocuklarda sosyal çevrelerine yönelik farkındalık kazandırılmasını sağlamaktadır.

Çocuklar doğdukları andan itibaren merakla kendilerini ve çevrelerini soru sorarak, dokunarak keşfetmeye çalışırlar. Daha sonra bu durum okul öncesi eğitim döneminde keşfederek öğrenme şeklinde sistematikleşmektedir. Çocukların bu doğal merakı proje yaklaşımı uygulamalarında onlara sosyal çevre alanıyla ilgili bilgilerin kazandırılmasında avantaj sağlamaktadır. Çocuklar için önemli bir konun detaylı olarak keşfedilmesi olarak tanımlanan proje yaklaşımı, çocukların kendi sorularını yanıtlama ve dünya hakkında daha fazla bilgi edinmenin yollarını sunar (Harte 2010 akt. Oğuz, Gizir \& Köksal Akyol 2014). Proje yaklaşımında çocuklar kitapları, posterleri, grafikleri, oyunları, fen deneylerini, görüşmeleri, raporları, videoları, modelleri, alan çalışmalarını, sanat çalışmalarını, dramayı kullanarak bilgilerini oluşturmaktadırlar (Wolk 1994). Proje çalışmalarında öğretmen bir rehber ve danışman rolü üstlenmektir. Öğretmen çocukları teşvik etmekte, seçenekler sunmakta, çocuklara özgür olma ve yanlış yaptıklarında 
düzeltebilme imkanı vermekte, çocuklarla birlikte araştırma yaparak bilgileri beraber keşfetmektedir (Temel et al. 2004; Bıçakçı \& Gürsoy 2009).

Günümüzde popüler bir yaklaşım olarak kullanılan ve uzun bir geçmişe dayanan, John Dewey'in eğitime ilişkin görüşlerini içeren proje yaklaşımı, çocuğun çeşitli kaynakları kullanarak grup içinde işbirliğine dayalı, derinlemesine araştırma ve inceleme yapma becerilerini geliştirmektedir (Anlak \& Yılmaz 2004). Proje yaklaşımı, çocuklar için anlamlı bir konunun çok yönlü olarak derinlemesine incelenmesi olarak da ifade edilebilir (Yıldız-Bıçakçı \& Gürsoy 2010). Ayrıca proje yaklaşımı ile öğrenen çocuklar, yaparak yaşayarak ve daha önce öğrendikleri bilgileri farklı alanlarda kullanarak daha kalıcı öğrenmeler sağlanmış olurlar (Hamurcu 2003). Böylelikle çocukların keşfederek öğrenmede kullandıkları doğal merak duygusu ve sosyal çevrenin keşfederek öğrenmeyle daha etkili öğrenilmesi proje yaklaşımı süreçlerinde birbiriyle örtüşen bir yapı içinde yer almaktadırlar. Aynı zamanda proje yaklaşımı çocuğun merak ederek öğrenmek istediklerini öğrenmesine olanak sağlayan özelliği ile sosyal çevreyle ilgili bilgilerin öğrenilmesinde kalıcı öğrenmelerin gerçekleştirilmesini sağlayacaktır. Proje yaklaşımı aşamalar biçiminde uygulanmaktadır; ilk uygulama olan başlangıç aşamasında öğretmenin cesaretlendirmesiyle gerekli ön bilgiyi paylaşarak projeye giriş yapılır, ikinci aşama olan projenin geliştirme aşamasında alan çalışmasının yapıldığı, konun araştııldiğ 1 ve etkinliklerin uygulandığ1 aşamadır, üçüncü aşama olan projenin sonlandırma aşaması öğrenilenlerin özetlendiği ve paylaşıldığı son aşamadır (Katz \& Chard 2000).

Ülkemizde okul öncesi eğitim döneminde proje yaklaşımının kullanıldığı çalışmaların (Terzioğlu-Çakar 2005; Güven 2006; Kurt 2007; Canoğlu 2007; Obalı 2009; Bıçakçı 2009; Aral et al. 2010; Özaslan 2010; Yıldız-Bıçakçı \& Gürsoy 2010; Yılmaz, Beyazkürk \& Anlıak 2011; Şahin, Güven \& Yurdatapan 2011; Oğuz 2012; Angın 2013; Özkarabacak 2013; Özyürek et al. 2013; Ünsal et al. 2013; Yalçın \& Tekbıyık 2013; Gizgir 2013; Metin \& Aral 2014; Oğuz et al. 2014) genellikle 5-6 yaş grubundaki çocuklarla ve proje yaklaşımının bu döneme ait farklı gelişim alanlarındaki etkisini incelemeye yönelik yapıldığı, 4 yaş grubundaki çocuklarla yapılan çalışmaların yok denecek kadar az olduğu görülmektedir. Bu nedenle okul öncesi eğitimin erken döneminde özlerinde var olan keşfederek öğrenme becerilerinin korunmasında ve sosyal çevrelerini öğrenirken etkili öğrenme becerilerinin geliştirilmesinde proje yaklaşımının olumlu katkıları olacağı düşünülmektedir. Bu çalışmada okul öncesi eğitim döneminde daha küçük yaş grubundaki çocuklara uygulanan proje yaklaşımlı eğitimin çocukların sosyal çevreye yönelik bilgi düzeylerindeki değişimini görmek amaçlanmıştır. Bu çalışmanın amacı, okul öncesi eğitim döneminde dört yaş çocuklarına uygulanan proje yaklaşımının çocukların sosyal çevreye yönelik bilgi düzeylerindeki değişimini incelemektir.

\section{Yöntem}

Araştırmada nitel araştırmalardan durum çalışması deseni kullanılmıştır. Durum çalışması bir veya birkaç durumu bütüncül olarak analiz etmeye dayanır (Yıldırım \& Şimşek 2008). Bu çalışmada durum çalışmalarından "Öncesi-Sonrası Durum Çalışması" kullanılmıştır. Öncesisonrası durum çalışması uygulanan belirli bir programın, kararın öncesinde ve sonrasında değerlendirilmesidir (Jensen \& Rodgers 2001; Berg 2009). Bu araştırmada, öncesi-sonras1 durum çalışmasının öncesinde, çocukların sosyal çevre konusuna ait bilgi düzeylerini belirlemek amacıyla çocuklardan yaşadığı çevreye yönelik resim çizmeleri istenmiş ve bu konuya yönelik çocuklarla görüşme yapılmıştır. Böylece ön bilgi düzeyleri ortaya konulduktan sonra proje yaklaşımıyla bu konuya yönelik eğitim verilmiştir. Sonrasında ise proje yaklaşımının etkililiğini değerlendirmek amacıyla tekrar çocuklardan sosyal çevre konusuna yönelik resim çizmeleri istenmiştir ve bu konuya yönelik görüşme yapılmıştır. Öncesi ve sonrasındaki sonuçlar değer- 
lendirilmiştir. Proje yaklaşımının uygulanması haftada 2 gün yaklaşık 3 saat olmak üzere toplamda 42 saat sürmüştür. Çalışma öncesi ve sonrasında yapılan değerlendirmeler dahil olmak üzere 20 Ekim 2014 - 19 Aralık 2014 tarihleri arasında gerçekleştirilmiştir.

\section{Çalışma Grubu}

Araştırmanın başlangıcında uygulama sınıfına kayıtlı olan 8 çocuk çalışma grubuna alınmıştır. Ancak devamsızlığı olan ve çalışmalara yeterli katılımı sağlanamayan 2 çocuk çalışma grubundan çıkarılmıştır. Bu nedenle araştırmanın çalışma grubu 2014-2015 güz yarıyılında İzmir Küçükyalı Mesleki ve Teknik Anadolu Lisesi'nin uygulama sınıfinda eğitim görmekte olan 6 çocuktan oluşmuştur. Çalışma grubunun seçiminde ölçüt örnekleme kullanılmıştır. Bu çalışmada önceden belirlenmiş ölçüt, proje yaklaşımının dört yaş grubundaki çocuklarla çalışılması olarak kabul edilmiştir. Çalışmada ölçüt olarak yaş alınmıştır.

\section{Veri Toplama Aracı}

Görüşme formunun geliştirilmesi aşamasında okul öncesi dönemde sosyal bilgiler öğretimiyle ilgili alanyazın taraması (Taylor 1999; Perry 2002; Tuğrul \& Güler 2007; Akengin \& Süer 2011; Can-Yaşar et al. 2012; Aktın 2014; Kılıç, Güleç \& Genç 2014) yapılmıştır. Bu sonuçlar doğrultusunda geliştirilen sorular konu alanı uzmanı iki öğretim elemanın incelemesi istenerek onların görüş ve önerileri alınmıştır. Görüşmelere başlamadan önce görüşme sorularını denemek için dört yaşındaki 2 çocuk ile ön görüşme yapılmıştır. Ön görüşmeler sonrasında son biçimi verilen 12 soruyla standartlaştırılmış açık uçlu görüşme yapılmış ve sorular aynı gün içinde ikiye bölünerek çocuklara uygulanmıştır. Araştırmanın öncesinde ve sonrasında aynı sorular çocuklara sorulmuştur. Görüşmede yer alan sorulara ait yanıtlar için çocukların aileleri ve öğretmeni ile görüşülerek derecelendirmeli bir yanıt formu hazırlanmıştır. Çocukların verdikleri yanıtlar bu yanıt formuna göre değerlendirilmiştir. Sorulara verilen yanıtlar tek yanıtı ve birden çok yanıtı olan şeklinde sınıflandırılmıştır. Tek yanıtı olan sorular doğru, yanlış ya da cevapsız olarak değerlendirilmiştir. Tek yanıtı olan sorulara sadece doğru cevap verenlerin gelişme gösterdiği kabul edilmiştir. Birden çok yanıtı olan sorular için ise derecelendirme yapılarak iyi ve çok iyi düzeyde yanıt verenlerin yanıtları gelişme gösteriyor olarak kabul edilmiştir. Derecelendirmeye göre geliştirilmesi gereken yanıtlar son görüşmede yeterli olarak görülmemiştir. Resim değerlendirmesi için çocuklara "Yaşadiğın yerde gördüklerinin resmini yapar mısın?" sorusu sorularak yaşadığı yere ilişkin çizimler yapmaları sağlanmıştır. Çocuklar resimlerini tamamladıktan sonra resimlerinde yer alan figürler, konum, yer, nesne vb. hakkında çocuklarla konuşulup her birinin resmindeki figürlerin, nesnelerin, yerlerin onlara göre neyi ifade ettiği çocuklara sorulmuş ve resimlerin üzerine bu bilgiler eklenmiştir. Bu bilgilere dayanarak resimlerin betimlenmesi ve karşılaştırmalı analizi yapılmıştır. Araştırmanın verileri 2 ayrı veri toplama yöntemi kullanılarak elde edilmiştir. McMillan (2004), özel durum çalışmaları yapılırken durumu daha derinlemesine betimlemek ve araştırmanın amacına uygun bir şekilde yürütülebilmesine olanak sağlamak için araştırmacının iki ya da daha fazla veri toplama yöntemi kullanılmasının gerekli olduğunu belirtmiştir. Bu çalışmada veriler çocuklar ile yapılan görüşmeler ve çocukların çizdikleri resimler ile toplanmıştır.

\section{Verilerin Analizi}

Görüşme sonucunda elde edilen veriler içerik çözümlemesi tekniğiyle çözümlenmiştir. İçerik çözümlemesinde temel amaç, toplanan verileri açıklayabilecek kavramlara ve kategorilere ulaşmaktır (Yıldırım \& Şimşek 2008). Görüşme sonuçlarının çözümlenmesi amacıyla kayıtlar gözden geçirilerek çocukların sorulara verdikleri yanıtlar araştırmacı tarafından kodlanmıştır. Gü- 
venirlik için araştırmacı tarafından yapılan kodlamalar üzerinde $\mathrm{P}=\frac{N a}{N a+N d}$ formülü uygulanmıştır (Miles \& Huberman 1994). ("P uyuşum yüzdesi", "Na uyuşum miktarı" ve "Nd uyuşmayan miktar") Yapılan kodlamaların güvenirliğini belirlemek için görüşme sonuçları araştırmacı tarafindan farklı zamanlarda tekrar kodlanarak, kodlamalar arasında uyuşum yüzdesi \%93 olarak hesaplanmıştır. Görüşmeler sonucunda elde edilen veriler içerik çözümlemesi tekniğiyle çözümlenmiş ve temel amaç olarak toplanan verileri açıklayabilecek kavramlara ve kategorilere ulaşmak hedeflenmiştir (Yıldırım \& Şimşek 2008). Çocukların verdikleri yanıtlar maddeler halinde yazılmış, çözümleme sonuçları ön-son görüşmeler şeklinde tablolaştırılmıştır.

Çocukların çizdikleri resimler ise her bir çocuk için ilk ve son çizilen resimlerdeki figür, konum, yer, nesne vb. betimlenmiş ve kullanımındaki farklılıklar dikkate alınarak karşılaş̧ırmalı olarak analiz edilmiştir. Resimlerin kodlama güvenirliği sağlamak amacıyla araştırmacı tarafından anlamsal açıdan incelenmiş ve ilgili alanyazına dayalı olarak önceden hazırlanan kod listesinden yararlanılarak, resimlerde işlenen her bir konuya isim verilmiştir. Analizlerde formül (Miles ve Huberman 1994) "P uyuşum yüzdesi", "Na uyuşum miktarı" ve "Nd uyuşmayan miktar" ile kodlamaların güvenirliğini belirlemek için görüşme sonuçları araştırmacı tarafından farklı zamanlarda tekrar kodlanarak, kodlamalar arasında uyuşum yüzdesi \% 95 olarak hesaplanmıştır.

\section{Proje Uygulama Süreci}

Sosyal çevrenin öğretiminde "Sosyal Çevre" konusunun içeriğinde araştırmacı tarafından yakından uzağa ilkesine bağlı kalınmıştır. Çocuklara sosyal çevreleriyle ile ilgili bilgileri öğretmeye başlarken, ailelerinden, komşularından, sınıflarından yani yakın çevrelerinden yola çıkılmış ve böylelikle anlaşılırlık arttırılmaya çalışılmıştır. Ayrıca okul öncesi dönem için alan yazında yer, konum teması ve tarih kapsamında yer alan içerik kullanılmıştır ve bu içerik program hazırlama ilkeleri göz önünde bulundurularak yerleştirilmiştir (Risinger 1992; Tuğrul \& Güler 2007; Hannibal, Vasiliev \& Lin 2002 akt. Tuğrul \& Güler 2007; Can-Yaşar et al. 2012). İçerikte Evimiz ve Evimizin Bulunduğu Çevre, Evimizde Birlikte Yaşadığımız Kişiler ve Komşularımız, Sınıfımız ve Sınıfımızda Birlikte Olduğumuz Kişiler, Okulumuz ve Okulumuzdaki Kişiler, Yaşadığımız Şehir İzmir yer almaktadır. "Sosyal Çevre" konusunun içeriği proje yaklaşımının başlangıç aşaması, araştırma aşaması ve sonuçlandırma aşaması süreçleri dikkate alınarak tasarlanıp, araştırmacı tarafından uygulanmıştır.

Projeye Giriş Aşamast: Proje yaklaşımlı eğitimin uygulama sürecinin başlangıç aşamasında ilk gün konuyla ilgili ön bilgi verilmiş ve konu ağı hazırlanmaya başlanmıştır. Bunun için sınıfa büyük konu ağı kağıdı getirilmiştir. Daha sonra çocukların ilgisini çekmek için sosyal çevre içerikli Tübitak Yayınlarından "Yavru Köpek" adlı hikaye anlatılmış ve bu hikayeye ait görseller çocuklarla paylaşılmıştır. Sonra çocuklarla hikayeden yola çıkarak kendi yaşadıkları çevrede neler gördüklerine ilişkin beyin firtınası yapılmıştır. Çocukların yaşadığı çevreyi çağrıştıran görseller çocuklarla beraber seçilerek konu ağının ortasına yapıştırılmış ve sınıfa asılmıştır. Son olarak çocuklara yaşadıkları çevreyle ilgili neler öğrenmek istedikleri sorulmuş ve bunun resmini yapmaları istenmiştir. Yapılan resimler konu ağı üzerine asılmıştır. Böylelikle her çocuğun ilgileri, deneyimleri, merak ettikleri ve öğrenmek istedikleri belirlenerek konu ağ ve etkinlikler ağı oluşturulmuştur. Bu konu ağına bağlı olarak yapılması planlanan etkinliklerden geziler, gerekli malzemeler, aile katılımlı çalışmalar ve tarihleri hakkında mektupla ailelere bilgi verilmiştir.

Projeyi Geliştirme Aşaması: Bu aşamada bir önceki aşamada planlanan etkinlikler uygulanmaya başlanmış ve çocukların bir önceki aşamada merak ettikleri ve öğrenmek istediklerini belirttikleri bilgilere ulaşmalarını sağlayıcı etkinlikler yapılmıştır. Çocuklar alan gezilerinden, 
yetkili kişiler ile görüşmelerinden, kitaplardan, dergilerden, internetten yararlanarak elde ettikleri bilgileri sanat çalışmaları, drama, dil etkinlikleri, matematik etkinlikleri, fen çalışmaları ile birleştirmişlerdir. $\mathrm{Bu}$ süreçte araştırmacı çocukları çalışma, kaynaklara ulaşma, bilgileri toplama, rekabetsiz tartışma yapma gibi konularda desteklemiştir.

Birinci Etkinlik Küçük Dedektifler: Bu etkinlik için öncelikle ailelerden çocuklarıla birlikte evlerinin bulunduğu apartmanı varsa bahçesini, sokağında bulunan market, park gibi yerleri, arabaları, tabelaları, ağaçları vb. incelemeleri ve video ile çekim yapmaları istenmiştir. Ailelerden bu çekimleri yaparken gördükleri yerler hakkında çocuklarla konuşmaları ve çekime bunları da kaydetmeleri istenmiştir. Daha sonra alan gezisi çekimleri CD’lere yüklenerek sınıfa gönderilmiş ve izlenen görüntüler hakkında çocuklarla sohbet edilmiştir. Sınıfa getirilen artık malzemeler ile her bir çocuğun evini ve evinin bulunduğu sokağın küçük bir modelini arkadaşları ile çalışarak yapması sağlanmıştır. Bu etkinlikte çocukların evlerine ve bulundukları çevreye ilişkin bilgileri keşfetmesi amaçlanmıştır.

Íkinci Etkinlik Kimleri Tanıyoruz: Bu etkinlik öncesinde ailelerden çocukların evlerinde beraber yaşadıkları kişiler ve komşuları hakkında çocuklarla sohbet etmeleri istenmiştir. Sınıfta da etkinliğe başlamadan çocuklarla evlerinde yaşayan kişiler ve komşularının kimler olduğu hakkında konuşulmuştur. Daha sonra sanat çalışmasında mukavva üzerinde kendilerine ayrılan bölümde tuz seramiği kullanarak çocukların her biri evlerinde beraber yaşadıkları kişileri oluşturmuşlar ve parmak boyası ile oluşturdukları figürleri boyamışlardır. Daha sonra gerçekleştirilen drama çalışmasında çocuklar evlerinde beraber yaşadıkları kişileri ve komşularını canlandırmışlardır. Bu etkinlikte evlerinde birlikte yaşadıkları kişileri tanıtmaları ve komşularını araştırma yaparak öğrenmeleri amaçlanmıştır.

Üçüncü Etkinlik Sinıfta Hep Beraberiz: Bu etkinlikte sınıfımızda birlikte olduğumuz kişiler ile ilgili çalışmalar yapılmıştır. İlk olarak çocuklara Kaknüs Çocuk Yayınlarının "Cemile Okula Dönüyor" adlı okulda geçen olayları ve kişileri içeren bir hikaye kitabı okunmuş ve çocuklarla bu kitapta yer alan bilgilerden yola çıkarak kendi sınıfındaki kişiler ile karşılaştırmalar yapmaları istenmiştir. Bu için "Cemile'nin okulu sizinkine benziyor mu?", "Sizin hangi arkadaşlarınız ve ögretmenleriniz var?" "Arkadaşlarınızın nasıl özellikleri var?" gibi sorular yöneltilerek daha ayrıntılı düşünmeleri sağlanmıştır. Daha sonra bireysel olarak sınıfta birlikte oldukları kişileri çizmeleri ve bu resimlerini sınıf arkadaşlarına anlatmaları istenmiştir. Bu etkinlikte hikayeden yola çıkarak sınıflarında bulunan kişilere yönelik farkındalık geliştirmeleri amaçlanmıştır.

Dördüncü Etkinlik Sinıfim Benim: Bu etkinlikte önce çocuklara sınıfın fiziksel özellikleri hakkında neler bildikleri sorulmuş ve sınıfın fiziksel özelliklerinin renk, şekil, sınıfın içinde yer alan eşyaları vb. kapsayabileceğinden bahsedilmiştir. Kendi sınıflarıyla ilgili hangi bilgileri öğrenmek istedikleri sorulmuştur. Çocukların merak ettikleri noktaları keşfetmelerini kolaylaştırmak amacıyla dergilerden fiziksel özellikleri yansıtan resimler bulmaları istenmiş ve bunları kendi sınıflarıyla karşılaştırmalarına yardım edilmiştir. Daha sonra sınıfın fiziksel özellikleri ile ilgili çalışmalar yapılmıştır. Her bir çocuktan sınıfa asılan grafiklerde sırasıyla nesne resminin altına sınıfta bu nesnenin bulunma sayısı kadar markayı sayarak yapıştırmaları istenmiştir. Daha sonra hazırlanmış olan grafiği de dikkate alarak sınıfa getirilen artık malzemeler ile bütün sınıf çalışmasında çocuklar işbirliği ile bir sınıf modeli oluşturmuşlardır. $\mathrm{Bu}$ etkinlikte çocukların ilgileri doğrultusunda çevrelerinde bulunan nesne, şekil gibi özelliklere farkındalık geliştirmeleri ve mekânsal ilişkileri keşfetmeleri amaçlanmıştır.

Beşinci Etkinlik Okul Gezgini: Bu etkinlikten önce çocuklarla ön görüşme yaparak okulla ilgili merak ettikleri üzerine konuşulmuştur. Sonra bu konuşulanlar üzerine okulun fiziksel özellikleri ve okuldaki kişiler ile ilgili çalışmalar amacıyla çocuklara okulda keşif gezisi 
yapacakları belirtilmiştir. Okulda çalışan kişilerin çalıştıkları yerlere giderek bu kişilere sormak istedikleri soruları sorarak ne işler yaptıkları hakkında bilgi edinmişlerdir. Ayrıca çocuklara fotoğraf makinesi verilerek gezdikleri yerlerin fotoğraflarını çekmeleri sağlanmıştır. Sınıfa döndükten sonra çocuklarla bugün kimlerle tanıştıkları, bu kişilerin hangi görevleri yaptıkları, okulun hangi bölümlerden oluştuğu hakkında sohbet edilmiştir. Daha sonra çocukların bir önceki etkinlikte hazırlamış oldukları sınıf maketinin üzerine okulla ilgili artık malzemelerden yaptıkları sanat çalışmalarını ekleyerek maketi okul maketi şeklinde genişletmişler ve çektikleri fotoğrafları da bu maket üzerinde ilgili yerlere yapıştırmışlardır. Konu ağı çalışmasında okulun bulunduğu semt hakkında çocukların bazı bilgileri öğrenmek istedikleri belirlenmiş ve çocukların bu konudaki merakları doğrultusunda ailelerden çocukları ile birlikte okulun bulduğu semti gezmeleri ve semt isminin geçtiği tabelalara dikkat çekmeleri istenmiştir. Bu etkinlikte fiziksel özelliklere ve ilişkilere yönelik araştırma yapma, görev ve sorumluluk bilinci kazandırılması amaçlamıştır.

Altıncı Etkinlik İzmirli Aşçılar: "Yaşadığımız Şehir İzmir" etkinliğinde yemeklerle ilgili etkinliklerde öncelikle çocuklardan etkinlik öncesinde aileleri ile beraber İzmir'e özgü yemekler hakkında araştırma yapmaları ve çocuklardan buldukları resimleri ve yemek tariflerini okula gelirken yanlarında getirmeleri istenmiştir. Okulda çocukların getirdikleri yemek tarifleri arasından İzmir köfte ve lokmanın tarifleri çocuklarla üzerinde çalışılmak için seçilmiştir. Bu yemeklere yönelik yemek tarifleri ve resimleri çocuklarla beraber incelenmiştir. Aynı zamanda okul mutfağında aşçının nasıl yemek pişirdiğini gözlemeleri sağlanmıştır. Daha sonra bu yemeklerin hangi malzemelerden oluştukları ve nasıl pişirildikleri üzerine bir oyun oynanmıştır. Daha sonra oyun hamurları ile kendilerine verilen kaplara tariflere bağlı olarak bu yemekleri oluşturmuşlardır. $\mathrm{Bu}$ etkinlikte yerel kültürel özelliklere yönelik bilgiyi keşfetmeleri amaçlanmıştır.

Yedinci Etkinlik İzmir'i Tanıyorum: "Yaşadığımız Şehir İzmir" etkinliğinde gezilecek yerlerle ilgili çalışmalarda çocuklardan aileleri ile beraber İzmir'in gezilecek yerleri hakkında araştırma yapmaları istenmiştir. Ayrıca inceleme gezisinde gidebildikleri yerlere de çocuklarıyla beraber giderek geziler yapmışlar ve fotoğraflar çekmişlerdir. Çocuklar gezilecek yerlere ilişkin buldukları bilgileri, resimleri, çektikleri fotoğrafları, kartpostalları okula getirmişlerdir. Okulda her bir çocuğun getirdiği fotoğraf, bilgiler, resimler üzerinde konuşulmuş ve merak ettikleri sorulara yönelik bilgiler verilmiştir. Daha sonra kartpostal çalışması yapılmıştır. Kartpostalı yapılacak yerler çocuklarla beraber belirlenmiştir. Doğal Yaşam Parkı, Kordon, İzmir Fuarı, Tarihi Asansör, Saat Kulesi olarak seçilmiştir. Bu etkinlikte tarih ve kültür kavramlarını keşfederek öğrenmesi amaçlanmıştır.

Projeyi Sonlandirma Aşaması: Bu aşamada sergi ve sunu çalışmaları yapılmıştır. Çocuklar buraya kadar öğrendikleri ve gözlemledikleri bilgilerinden oluşturulmuş resim, fotoğraf, sanat etkinleri vb. çalışmalarını davet ettikleri aileleri paylaşmışlardır. Bu paylaşım için bir sergi düzenlenmiştir. Aynı zamanda çocukların süreç içerisinde çalışırken çekilmiş fotoğrafları da sergilenmiş̧ir. Sergi çocuklar ve araştırmacı ile beraber hazırlanmıştır. Ayrıca çocuklar sonuçlandırma aşamasında öğrendikleri bilgileri içeren bir drama etkinliğini seyirciler önünde sergilemişlerdir.

Projeyi Değerlendirme Aşaması: Projenin bu aşamasında uygulama süreci öncesinde çocukların sosyal çevrelerine yönelik bilgi düzeylerini değerlendirmek üzere çocuklarla görüşme yapılmış ve yaşadıkları çevreye yönelik resim çizmeleri istenmiştir. Uygulama süreci tamamlandıktan sonra da çocukların sosyal çevrelerine yönelik bilgi düzeylerini değerlendirmek üzere tekrar çocuklarla görüşme yapılmış ve yaşadıkları çevreye yönelik resim çizmeleri 
istenmiştir. Sonuçlar proje yaklaşımı ile çocukların sosyal çevreye ait bilgi düzeylerinde olumlu değişimlerin olduğunu göstermiştir. Bu projede aileler sergiye katıldıklarından dolayı çocuklarının gelişimlerini değerlendirmeye yönelik sorular sorma ve gözlem yapma olanağı bulunmuşlardır.

\section{Bulgular ve Yorum}

$\mathrm{Bu}$ çalışmada bulgular bölümünde okul öncesi dönemde proje yaklaşımı uygulanmasının öncesinde ve sonrasında görüşme ve resimler yoluyla toplanan veriler analiz edilerek çocukların sosyal çevrelerine ilişkin bilgi düzeylerindeki değişim ortaya konulmuştur.

\section{Dört Yaş Çocuklarıyla Sosyal Çevrelerine Yönelik Yapılan Görüşmeye Ait İlk ve Son Yanıtlarının Değerlendirilmesi}

Bulgularda çocukların görüşme verileri ana-alt temalar halinde tablolaştırılmış ve ön-son değerlendirmeler şeklinde yorumlanmıştır. Benzer bir biçimde resimler de sosyal çevre kavramlarına yönelik ilk ve son çizimler olarak değerlendirilmiştir. Çocukların görüşleri " $E v$, Aile ve Komşular, Ev Çevresi, Sınıf, Okul ve Şehir" ana temalarında toplanmıştır. Ana temalar ve alt temalar Tablo 1'de verilmiştir.

Tablo 1'de sadece "Evde birlikte yaşadı̆̆ımız kişiler" alt temasına yönelik bilgi düzeyleri ön görüşmede tam düzeyde bulunmuştur ve bu nedenle proje yaklaşımının uygulanmasından sonra bilgi düzeylerinde nicelik ve nitelik olarak herhangi bir değişimin görülmediği tek alt temadır.

Diğer tüm temalarda başlangiçta görüşleri olsa da proje yaklaşımının uygulanmasından sonra nicelik olarak artış görülmüştür. Ayrıca dört yaş dönemi çocuklarının sosyal çevrelerine yönelik ön görüşmede, şehre ait alt temalarda (A), (B), (C), (D), (E) ve (F) çocuğun bir görüş belirtmediği, proje yaklaşımlı eğitimin uygulanmasından sonra ise alt temaların hepsinde bilgi sahibi olduğu ve görüş belirttiği belirlenmiştir. $\mathrm{Bu}$ durum proje yaklaşımlı eğitimin uygulanmasından önce çocukların bilgi düzeylerinin en düşük olduğu alanın uzak çevreleri olduğunu göstermektedir. Proje yaklaşımlı eğitim çocukların uzak çevrelerine yönelik farkındalıklarının artmasını sağlamıştır.

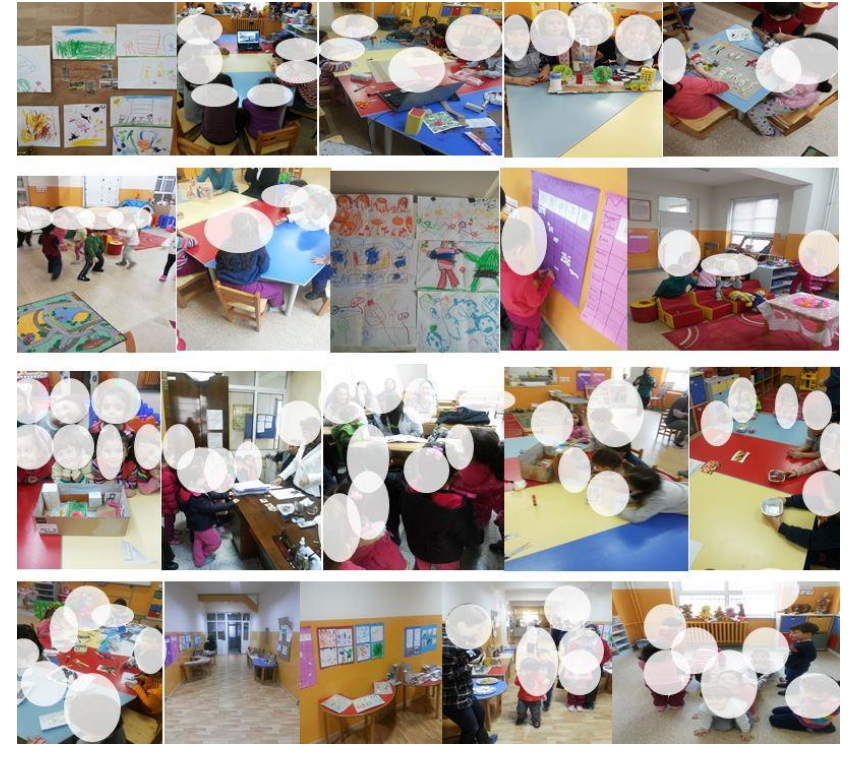

Fig. 1. Proje Yaklaşımlı Eğitimi Uygulama Sürecine Yönelik Fotoğraflar

Tablo 1. Sosyal Çevrelerine İlişkin Dört Yaş Çocuklarının Yanıtları

\begin{tabular}{|c|c|c|c|}
\hline & & Ön Yanıtlar & Son Yanitlar \\
\hline Ana Tema & Alt Temalar & \multicolumn{2}{|c|}{ Cocukların Adlarına İlisskin Kısaltmalar } \\
\hline \multirow{4}{*}{ Ev } & Binanın Rengi & & A,B,C,D,E,F \\
\hline & Binanın Şekli & $\mathrm{C}, \mathrm{D}, \mathrm{E}, \mathrm{F}$ & A,B,C,D,E,F \\
\hline & Binanın Ad 1 & & A,B,C,D,E,F \\
\hline & Binanın Numarası & $\mathrm{E}$ & B,C,D,E,F \\
\hline
\end{tabular}




\begin{tabular}{|c|c|c|c|}
\hline \multirow{2}{*}{$\begin{array}{l}\text { Aile ve } \\
\text { Komşular }\end{array}$} & \multirow{2}{*}{$\begin{array}{l}\text { Evde Birlikte Yaşadığımız Kişiler } \\
\text { Komsuların İsimleri }\end{array}$} & \multirow{2}{*}{$\begin{array}{l}\text { A, B,C,D,E,F } \\
\text { A,D,E,F }\end{array}$} & \multirow{2}{*}{$\begin{array}{l}\text { A,B,C,D,E,F } \\
\text { A,B,D,E,F }\end{array}$} \\
\hline & & & \\
\hline \multirow[b]{3}{*}{ Ev Çevresi } & Cadde/Sokak Numarası & & A,B,C,D,E,F \\
\hline & Evimiz Yokuşta/Düzde & $\mathrm{D}, \mathrm{E}$ & $\mathrm{A}, \mathrm{B}, \mathrm{D}, \mathrm{E}, \mathrm{F}$ \\
\hline & $\begin{array}{l}\text { Doğal Çevre (Bitki,Ağaç vb. ) } \\
\text { Yapay Çevre(Market,Park vb.) } \\
\text { Yaşanılan Semtin Adı }\end{array}$ & $\begin{array}{l}\text { C,D } \\
\text { A,B,C,D,E,F }\end{array}$ & $\begin{array}{l}\text { B,C,D,F } \\
\text { A,B,C,D,E,F } \\
\text { A,B,C,D,E,F }\end{array}$ \\
\hline \multirow{4}{*}{ Sinif } & Sınıfın Şekli & $\mathrm{E}$ & A,B,C,D,E,F \\
\hline & Sinıfin Duvarlarının Rengi & & A,B,C,D,E,F \\
\hline & Sınıfın içindeki Nesneler & $\mathrm{A}, \mathrm{B}, \mathrm{C}, \mathrm{D}, \mathrm{E}, \mathrm{F}$ & A,B,C,D,E,F \\
\hline & Sınıftaki Kişiler & $\mathrm{A}, \mathrm{B}, \mathrm{C}, \mathrm{D}, \mathrm{E}, \mathrm{F}$ & A,B,C,D,E,F \\
\hline \multirow{3}{*}{ Okul } & Okulun Adı & $\mathrm{E}$ & $\mathrm{A}, \mathrm{B}, \mathrm{C}, \mathrm{D}, \mathrm{E}, \mathrm{F}$ \\
\hline & Okulun İçinde Bulunan Yerler & $\mathrm{A}, \mathrm{B}, \mathrm{C}, \mathrm{D}, \mathrm{E}, \mathrm{F}$ & $\mathrm{A}, \mathrm{B}, \mathrm{C}, \mathrm{D}, \mathrm{E}, \mathrm{F}$ \\
\hline & $\begin{array}{l}\text { Okulun Bulunduğu Semtin Adı } \\
\text { Okulda Bulunan Kişiler } \\
\text { Okul Binasının Rengi }\end{array}$ & C,D & $\begin{array}{l}\text { A,B,C,D,E,F } \\
\text { A,B,C,D,E,F } \\
\text { A,B,C,D,E,F }\end{array}$ \\
\hline Şehir & $\begin{array}{l}\text { Șehrin Adı } \\
\text { Shehre Özgü Yemekler } \\
\text { Shehirde Gezilecek Yerler }\end{array}$ & & $\begin{array}{l}\text { A,B,C,D,E,F } \\
\text { A,B,C,D,E,F } \\
\text { A,B,C,D,E,F }\end{array}$ \\
\hline
\end{tabular}

Tablo 1 genel olarak değerlendirildiğinde dört yaş çocuklarının sosyal çevreye yönelik bilgi düzeylerinin ön görüşmede yeterli düzeyde olmadığı, daha çok en yakın sosyal çevrelerine yönelik görüş belirtebildikleri yakın çevrelerinden uzaklaştıkça bilgi düzeylerinde azalma olduğu belirlenmiştir. Ön görüşmelerde alt temalarının bazılarına yönelik bilgi sahibi olsalar da projeden sonra sahip oldukları bu bilgi düzeylerinde artış olmuştur. Proje yaklaşımının uygulanmasından sonra yapılan son görüşmelerde ön görüşmelere göre hem yakın hem de uzak sosyal çevrelerine yönelik daha fazla ve yeterli düzeyde bilgiye sahip oldukları görülmüştür.

\section{Dört Yaş Çocuklarının Sosyal Çevrelerine Yönelik Çizdikleri İlk ve Son Resimlerinin Değerlendirilmesi}

Çocukların çizimlerinde, ilk ve son resimler incelenerek karşılaştırıldığında, birden fazla konu da artış olduğu görülmüş ve bu artışlar 9 başlık altında toplanmıştır. Tablo 2 bu alanlarda çocukların ilk ve son resimleri arasındaki artış miktarını göstermektedir.

Tablo 2. Çocukların $(n=6)$ Resimlerine Yansıyan Sosyal Çevre Konularına Ait Artış Miktarı

\begin{tabular}{lccc}
\hline $\begin{array}{l}\text { Cocukların Resimlerine Yansıyan Sosyal Çevre } \\
\text { Konuları }\end{array}$ & İlk Resim & Son Resim & Artış Miktarı \\
\hline Ev & 5 & 6 & 0,2 \\
Aile ve Komşular & 11 & 25 & 1,27 \\
Ev Çevresi & 2 & 4 & 1,00 \\
Sinıf & 0 & 31 & - \\
Okul & 0 & 12 & - \\
Şehir & 1 & 11 & 10,00 \\
Sosyal çevre kompozisyonu oluşturma & 3 & 22 & 6,33 \\
Renklerin gerçeğe uygunluğu & 3 & 26 & 7,67 \\
Resimlerdeki ayrıntılar & 2 & 30 & 14 \\
\hline
\end{tabular}


Tablo 2'ye bakıldığında, çocukların ilk ve son çizimleri karşılaştırıldığında, bu çizimlerde evle ilgili yer verilen canlı ve cansız varlık sayısında 0,2 kat bir artış olduğu görülmüştür. $\mathrm{Bu}$ çizimlerde aile ve komşulara ait yer verilen insan figürü sayısında 1,27 kat bir artış olduğu, ev çevresine ait yer verilen canlı ve cansız varlık sayısında 1,00 kat artış olduğu, şehre ait canlı ve cansız varlık sayısında 10,00 kat artış olduğu görülmüştür Çocukların çizimlerinde sosyal çevre kompozisyonu oluşturmada ise çizimlerde 6,33 kat bir artış olduğu ve renklerin gerçeğe uygunluğunda 7,67 kat bir artış olduğu görülmüş. Çizimlerde, yer verilen canlı ve cansız varlıkların resimsel ayrıntılarında 14 kat bir artış olduğu görülmüştür. Sınıf ve okula ait yer verilen canlı ve cansız varlık sayısındaki artışın oldukça yüksek olduğu görülmektedir. Ancak ilk resim puanı sıfır olduğu için artış miktarı olarak hesaplanmamıştır.

Genel olarak dört yaş çocuklarının sosyal çevreye yönelik bilgi düzeylerinin ilk resimlerinde yer alan figür ve kavramlar açısından değerlendirildiğinde yeterli düzeyde olmadığı, daha çok en yakın sosyal çevrelerine yönelik çizimler yaptıkları görülmüştür. Uzak çevrelerine ait çizimlere yer vermemiş olmaları uzak çevrelerine yönelik bilgi düzeylerinin yeterli olmadı ̆̆ını düşündürmektedir. Proje yaklaşımının uygulanmasindan sonra yapilan son resimlerinde yer alan figür ve kavramlar açısından değerlendirildiğinde hem yakın hem de uzak sosyal çevrelerine yönelik daha fazla ve yeterli düzeyde bilgiye sahip oldukları söylenebilir. Ayrıca ilk resimlerde yakın çevrelerine ait çizimler tüm resmi kaplarken, son çizimlerinde hem yakın hem de uzak çevreden çok daha fazla çizimin resmin içine orantılı bir biçimde dağıtılarak yerleştirilmiş olması dikkat
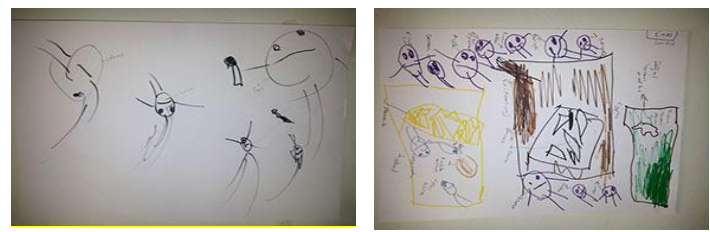

Fig. 2. Çocuk (A)'ya Ait İlk ve Son Resimler
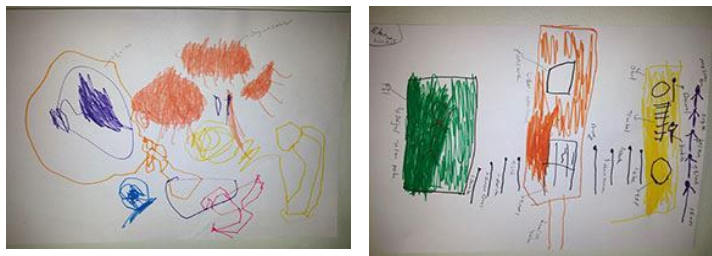

Fig. 3. Çocuk (B)'ye Ait İlk ve Son Resimler
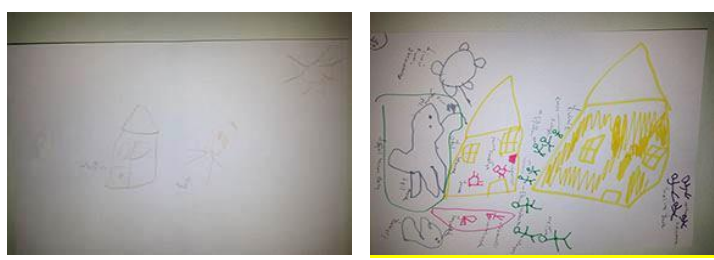

Fig. 4. Çocuk (C)'ye Ait İlk ve Son Resimler
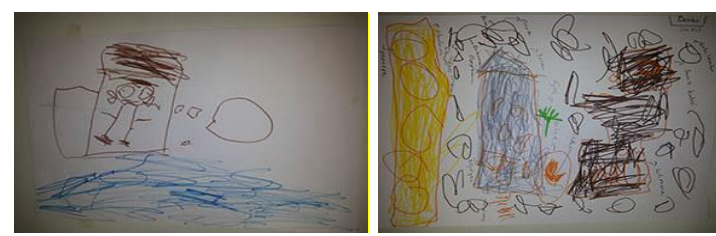

Fig. 5. Çocuk (D)'ye Ait İlk ve Son Resimler

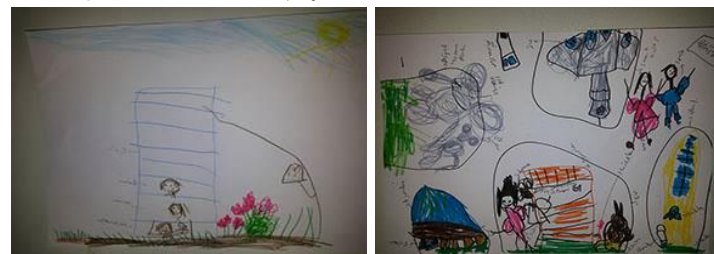

Fig. 6. Cocuk (E)'ye Ait İlk ve Son Resimler

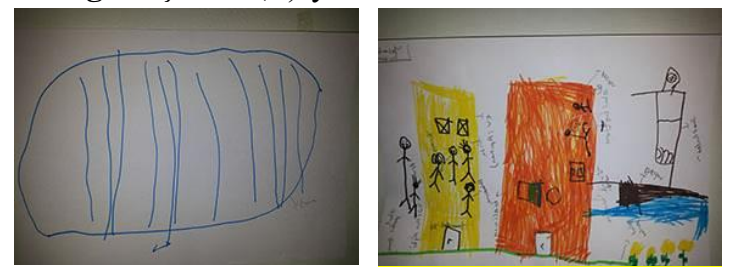

Fig. 7. Çocuk (F)'ye Ait İlk ve Son Resimler çekicidir. $\mathrm{Bu}$ değişim proje uygulamasından sonra çocukların zihinlerinde sosyal çevrelerine yönelik şemalarda meydana gelen değişimin bir yansıması olarak da değerlendirilebilir. Ayrıca görüşme ve çizimlerden elde edilen bulguların birbirini desteklediği görülmektedir.

\section{Sonuç, Tartışma ve Öneriler}

Çizilen resimlerden ve görüşmelerden elde edilen sonuçlarda ana ve alt temalarda sosyal çevre kavramlarına (ev, evimizin çevresi, evde birlikte olduğumuz kişiler ve komşular, okulum, sınıfimız, İzmir vb.) yönelik artış olduğu görülmektedir. Araştırma sonucunda çocuklarla yapılan önson görüşmeler ve ilk-son çizimler arasında bilgi düzeylerinde olumlu değişim olduğuna yönelik 
veri toplanmıştır. Sonuç olarak okul öncesi eğitim döneminde 4 yaş çocuklarına proje yaklaşımlı eğitim uygulamasının çocukların sosyal çevreye yönelik bilgi düzeylerinde olumlu yönde değişimin oluşturduğu söylenebilir. Bu araştırmadan elde edilen sonuçlar başka araştırmaların sonuçları ile benzerlik göstermekte ve onları desteklemektedir. Ayrıca bu araştırmada okul öncesi dönemde küçük yaş gruplarında proje yaklaşımı çalışılarak da olumlu sonuçlar elde edileceği saptanmıştır. Yurt dışında yapılan çalışmalara bakıldığında 3-5 yaş aralığında proje yaklaşımıyla ilgili araştırmaların yoğun olarak yapıldığı (Aghayan et al. 2005; Elizondo \& Valencia 2006; Sánchez 2007; Gallick \& Lee 2009; Harkema 2009) hatta proje yaklaşımıyla 2.9 ile 3.9 yaşları arasında yapılmış olan (Harden \& Verdeyen 2007) çalışmaların yer aldığı belirlenmiştir.

Bedir ve et al. (2006) çok kültürlülük temasının erken çocukluk döneminde kazandırılmasına yönelik bir proje çalışmasında dünya üzerindeki tüm çocukların çeşitli kültürel özelliklerini, oyunlarını, şarkılarını, ninnilerini, kıyafetlerini, özel günlerini, yemeklerini, gelenek ve göreneklerini tanıyıp, çocukların kendileri dışındaki dünyayı keşfetmelerine yardımcı olmayı amaçlamışlardır. Projenin uygulanması sürecinde, aile katılımı, gezi-gözlem, deney, oyun, eğitici drama, dil etkinliği, sohbet, tartışma, çalışma sayfaları ve sanat çalışmalarına yer vermişlerdir. Araştırma sonucunda, yapılan etkinliklerin çocukların farklı kültürleri tanımaları ve bunlar arasındaki benzerlikleri ve farklılıklarını kavramaları, bu kültürlere hoşgörü ve barış çerçevesinde yaklaşmaları üzerinde olumlu etki yarattığını saptamışlardır. Proje çalışmasının, çocukların zihinsel gelişim, dil gelişimi, yaratıcılık, sosyal beceriler ve entelektüel gelişimleri üzerinde olumlu etkileri olduğunu proje bitimindeki değerlendirmelerde tespit etmişlerdir. Bedir ve diğerlerinin çalışmasında proje çalışması ile çocukların çok kültürlülük kavramlarına yönelik bilgilerinde artış olduğunu belirlemiştir. Benzer bir biçimde bu çalışmada da proje yaklaşımı ile çocukların sosyal çevrelerine yönelik bilgi düzeylerinde artış olduğu saptanmıştır.

Aghayan ve et al. (2005), Louisiana'da yaşayan 3-4 yaşlarındaki bir grup çocukla "Katrina Projesi"ni yürütmüşlerdir. Proje, Katrina Kasırgası'ndan sonra yaşadıklarından hareketle ortaya çıkmıştır. Projede yer alan fotoğraflar ve diğer belgeler, proje süresince sırasıyla çocukların çalışmalarını ve neler öğrendiklerini göstermektedir. Proje sonrasında aileler kendilerinin ve çocuklarının daha az stresli olduklarını, tahliye ile ilgili çocuklarının ve kendilerinin çok şey öğrendiklerini belirtmişlerdir. Bu çalışmada belirlenen bilgi artışına benzer bir şekilde Aghayan et al. dört yaş dönemindeki çocuklar ile proje yaklaşımlı ögrenmeyle çalışmışlar ve kasırgaya yönelik alınabilecek önlemler konusunda çocukların bilgi düzeylerinde artı̧̧ olduğunu belirlemişlerdir.

Sánchez (2007), 3, 4 ve 5 yaşlarındaki çocukların sağlık tesislerinin incelenmesi içeren “Hastane Projesi”ni yürütmüştür. Çocuk hastaneleri, beslenmeleri ve kendi vücutları hakkında pek çok şey öğrenmişlerdir. Proje sonucunda çocukların kullandıkları kelimeler artmıştır. Doktorların kullandıkları araçları ve onları kullanma nedenlerini öğrenmiş̧lerdir. Çocukların çoğu bazı iç organları ve işlevlerini tanımlamayı başarmıştır. Farklı gıda kategorilerini öğrenmişlerdir. Çocukların bu projeden elde ettikleri en önemli şey kendilerine güvenleri artmıştır ve çocuklar sosyal becerileri kazanmıştır. Projenin başında çocukların hastane ile ilgili endişeleri proje sonunda çözülmüştür. Obalı (2009) ise araştırmasında, okulöncesi eğitimi almakta olan altı yaş grubu çocuklara proje yaklaşımı kullanılarak verilen beslenme eğitiminin, çocukların beslenme bilgi düzeyine olan etkisini incelemeyi amaçlamıştır. Araştırma sonuçlarına göre, proje yaklaşımı kullanılarak verilen eğitimle, deney grubu çocuklarında kontrol grubu çocuklarına oranla besin gruplarına ilişkin bilgi düzeylerinde olumlu gelişmeler olduğu ortaya çıkmaktadır. Sánchez (2007) ve Obalı'nın (2009) çalışmalarında okul öncesi döneminde çocuklarla proje yaklaşımı çalışmaları sonucunda çocukların bilgi düzeylerindeki artış ifade edilmiş- 
tir. Benzer bir biçimde bu çalışmada da çalışılan konu üzerinde bilgi artışı gözlenmiştir.

Şallı (2011), proje tabanlı öğrenme yaklaşımı ile okul öncesi kurumlara devam eden 48-60 aylık çocuklara geri dönüşüm kavramını kazandırılmak için bir araştırma yapmıştır. Araştırmanın sonucunda, proje tabanlı öğrenme yaklaşımıyla hazırlanan geri dönüşüm programına katılmış olan deney grubundaki çocukların geri dönüşüm kavramı kazanımının, kontrol grubundaki çocuklara göre daha fazla geliştiği ve programın etkili olduğunu bulmuştur. Şallı'nın çalışmasında proje yaklaşımıyla geri dönüşüme yönelik kavramlarda artış saptanırken, bu benzer bir biçimde bu çalışmada da çalışılan konu üzerinde bilgi artışı gözlenmiştir.

Ünsal ve et al. (2013) çalışmalarında örneklem grubunu oluşturan 60-72 aylık okul öncesi dönem çocuklarının yaşadıkları şehir olan İstanbul'u ve İstanbul'un farklı tarihi mekanları tanımalarında aile katılımlı proje tabanlı programın faydalı olduğu sonucuna varmışlardır. Ünsal ve diğerlerinin çalışmasında da bu çalışmaya benzer olarak proje yaklaşımı ile sosyal çevreye yönelik çalışılmış ve bu araştırmadaki gibi olumlu sonuçlar elde edilmiştir. Yalçın ve Tekbıyık (2013) çalışmalarında çocukların yaşadıkları çevrede her zaman karşılaştıkları deniz ve denizle ilişkili kavramlar konusunda proje yaklaşımının öğrencilerin kavramsal gelişimlerine etkisini incelemektir. Çocukların çizimlerinden ve mülakatlardan elde edilen veriler içerik analizi yöntemiyle analiz edilmiştir. Bu çalışma sonunda elde edilen bulgular doğrultusunda çocukların deniz ve deniz canlılarına yönelik kavramsal gelişimlerinde belirgin bir farklılık olduğu ortaya konulmuştur. Bu araştırmaya benzer bir biçimde Yalçın ve Tekbıyık (2013) çalışmasında proje yaklaşımıyla çalışan konuda çocukların gelişmelerin gözlenmesinde mülakat ve resim analizleri kullanılmış ve kavram düzeylerinde artış belirlenmiştir Özkarabacak (2013) ise 60-72 aylık çocuklar için aile katılımlı proje tabanlı öğrenme yaklaşımıyla uygulanan programın çocukların farklı kültürlere bakış açılarına olan etkisini incelemiştir. Araştırmanın sonucunda deney grubunun farklı kültürlere ilişkin bakış açılarında, kontrol grubuna oranla artış saptanmıștır. Özkarabacak (2013) çalışmasına benzer bir biçimde bu çalışmada da çocukların sosyal çevreleri kapsamında kültürlerine ilişkin bilgi düzeylerinde artış olmuştur.

$\mathrm{Bu}$ araştırmadan elde edilen sonuçlar doğrultusunda ileriye yönelik boylamsal bir çalışma yapılıp, okul öncesi dönemde yapılan çalışmaların çocukların ilerideki sosyal çevre farkındalığını bu tür çalışmalara katılmayan çocuklara göre nasıl etkileniyor olduğu incelenmelidir. Sosyal çevre üzerine aileleri ve çocukları bir arada değerlendiren ve aralarındaki etkileşimi inceleyen araştırmalar yapılmalıdır. Proje yaklaşımının yaratıcı düşünme becerisi, psikomotor beceriler, sosyal beceriler, bilimsel süreç becerileri vb. gibi değişkenlere etkisini belirlemeye yönelik deneysel çalışmalar yapılmalıdır. Farklı konularda yapılan proje yaklaşımlı eğitimin sonuçları değerlendirilmelidir. Uygulanan proje yaklaşımına dayalı eğitim programlarının etkililiğini kontrol etmek için hem süreç hem de sonuç değerlendirmeye yönelik çalışmalar yapılmalidir.

\section{KAYNAKÇA}

Aghayan C., Schellhaas A., Wayne A., Burts D. C., Buchanan T. K. \& Benedict J. (2005). "Project Katrina”. Early Childhood Research and Practice 7/2 (2005) 1-10.

Ahioğlu-Lindberg, N. E. (2012). "Çocuk Yetiştirme Açısından Türkiye'de Çocukluğun Tarihi". Pamukkale Üniversitesi Eğitim Fakültesi Dergisi 31 (2012) 41-52.

Akengin H. \& Süer S. (2011). "Coğrafi Kavramlar Bakımından Öğrencilerin Hazırbulunuşluk Düzeyleri ve Bu Kavramların Geliştirilmesi Üzerine Deneysel Bir Araştırma”. Marmara Coğrafya Dergisi 24 (2011) 26-48. 
Aktın K. (2014). "Okul Öncesi Dönemde Sosyal Bilgiler Eğitimi: Mesleklerin Öğretimine Yönelik Bir Durum Çalışması”. Turkish Studies 9/5 (2014) 139-155.

Angın D. E., (2013). Proje Temelli Eğitim Programının 60-71 Aylık Çocukların Kavram Gelişsimine Etkisi. Yayımlanmamış Doktora Tezi. Selçuk Üniversitesi, Konya 2013.

Anlak Ş. \& Yılmaz H. (2004). "Kuramsal Bakış Açısıyla Proje Yaklaşımı". Eurasian Journal of Educational Research 17 (2004) 17.

Aral N., Kandır A., Ayhan A. \& Can-Yaşar M. (2010). "The Influence of Project-Based Curricula on SixYear-Old Preschoolers' Conceptual Development”. Social Behavior and Personality: An International Journal 38/8 (2010) 1073-1080.

Bedir D., Aktan-Kerem E. \& Alyüz S. (2006). "Çok Kültürlülük Temasının Erken Çocukluk Döneminde Kazandırılmasına Yönelik Bir Proje Çalışması". 3. Uluslararası Çocuk ve İletişsim Kongresi \& 3. Uluslararası Çocuk Filmleri Festivali-Kongresi Bildirileri, 6-8 Kasım 2006 (2006) 157-162.

Berg B. (2009). Qualitative Research Methods for the Social Sciences. Boston 2009.

Bıçakçı M. Y., (2009). Proje Yaklaşımına Dayalı Eğitimin Altı Yaş Çocuklarının Gelişsim Alanlarına Etkisinin İncelenmesi. Yayımlanmamış Doktora Tezi. Ankara Üniversitesi, Ankara 2009.

Elizondo L. \& Valencia L. (2006). "The Birds and Their Nests Project". Early Childhood Research and Practice 8/1 (2006) 1-10.

Can-Yaşar M., İnal G., Uyanık Ö. \& Yazıcı H. (2012). "Okul Öncesi Dönemde Coğrafya Eğitimi”. Elektronik Sosyal Bilimler Dergisi 11/30 (2012) 75-87.

Canoğlu M. (2007). "Okul Öncesi Eğitim Kurumlarına Devam Eden 6 Yaş Grubu Çocuklarda Proje Tabanlı Öğrenmenin Sezgisel Matematik Becerilerine Etkisi”. Yayımlanmamış Yüksek Lisans Tezi. Abant İzzet Baysal Üniversitesi, Bolu 2007.

Çoşkun M. (2004). "Coğrafya Öğretiminde Proje Yaklaşımı". Kırşehir Eğitim Fakültesi Dergisi 5/2 (2004) 99-107.

Gallick B. \& Lee L. (2009). “Cheesy Pizza: The Pizza Project”. Early Childhood Research and Practice $11 / 2(2009) 1-10$.

Gizgir E. (2013). Proje Yaklaşımının Anasınıfina Devam Eden Çocukların Yaratıcllıklarına Etkisinin Incelenmesi. Yayımlanmamış Yüksek Lisans Tezi. Ankara Üniversitesi, Ankara 2013.

Güven Y., Zembat R. \& Şahin F. (2004). "Proje Temelli Eğitimle Kavram Kazanımı". OMEP Dünya Konsey Toplantisl ve Konferansı Bildirileri (5-11 Ekim 2003). Cilt 2 (2004) 483-493.

Hamurcu H. (2003). "Okul Öncesi Eğitimde Fen Bilgisi Öğretimi: Proje yaklaşımı”. Eğitim Araştırmaları 13 (2003) 66-72.

Harden D. L. \& Verdeyen T. B. (2007). "The Baby Project". Early Childhood Research and Practice 9/2 (2007) 1-7.

Harkema R. (999). "The School Bus Project”. Early Childhood Research and Practice 1/2 (1999) 1-5.

Jensen J. \& Rodgers R. (2001). "Cumulating the Intellectual Gold of Case Study Research". Public Administration Reviev 61/2 (2001) 236-246.

Katz L. G. \& Chard S. C. (2000). "The Project Approach: An Overview. Roopnarine”. Ed. L. R. Jaipaul, \& E. J. Johson, Approaches to Early Childhood Education (2000) 175-189. New Jersey.

Kılıç-Özkan Ö., Güleç H. \& Genç S. Z. (2014). "Okul Öncesi Dönem Resimli Öykü Kitaplarının Coğrafi Kavramları İçermesi Yönünden İncelenmesi”. Ahi Evran Üniversitesi Kırşehir Eğitim Fakültesi Dergisi (KEFAD) 15/1 (2014) 35-52.

Kostelnik M. J., Gregory K. M., Soderman A. K. \& Whiren A. P. (2012). Guiding Childeren's Social Development and Learning. United Kingdom 2012.

Kurt F. (2007). Okul Öncesi Eğitim Kurumlarına Devam Eden Beş-Altı Yaş Çocuklarının Sosyal Uyum Becerilerine Proje Yaklaşımlı Eğitim Programlarının Etkisinin İncelenmesi. Yayımlanmamış Yüksek Lisans Tezi. Gazi Üniversitesi, Ankara 2007.

McMillan J. H. $\left(2004^{4}\right)$. Educational Research: Fundamentals for the Consumer. Boston 2004.

Metin Ş. \& Aral N. (2014). "Proje Yaklaşımına Dayalı Eğitimin Beş Yaş (60-72 Ay) Çocuklarının Çizim Becerilerine Etkisinin İncelenmesi”. Ĕgitim ve Öğretim Araştırmaları Dergisi 3/17 (2014) 180-194. 
Obalı H. (2009). Okulöncesi Eğitimi Almakta Olan Altı Yaş Grubu Çocuklarına Verilen Proje Yaklaşımıyla Beslenme Eğitiminin Beslenme Bilgi Düzeyine Etkisi. Yayımlanmamış Yüksek Lisans Tezi. Selçuk Üniversitesi, Konya 2009.

Oğuz V., Gizir Z. \& Köksal-Akyol A. (2014). Erken Çocukluk Eğitimde Proje Yaklaşımı ve Uygulanmış Proje Örnekleri. Ankara 2014.

Oğuz V. (2012). Proje Yaklaşımının Anasınıfına Devam Eden Çocukların Problem Çözme Becerilerine Etkisinin Incelenmesi. Yayımlanmamış Doktora Tezi. Ankara Üniversitesi, Ankara 2012.

Özaslan H. (2010). Proje Yaklaşımına Dayalı Eğitimin Anasınıfina Devam Eden Çocukların Okul Olgunluğuna Etkisinin İncelenmesi. Yayımlanmamış Doktora Tezi. Ankara Üniversitesi, Ankara 2010.

Özkarabacak A. B. (2013). Aile Katılımlı Proje Tabanlı Öğrenme Yaklaşımının 60-72 Aylık Çocukların Farklı Kültürlere Bakış Açısına Etkisinin Incelenmesi.Yayımlanmamış Yüksek Lisans Tezi. Marmara Üniversitesi, İstanbul 2013.

Özyürek A, Özkan İ., Bedge Z. \& Civliz S. (2013). "Proje Tabanlı Öğrenme Yöntemi ve Okul Öncesi Yaş Grubu Çocuklarla 'Televizyon Projesi'nin Uygulanması”. Uluslararası Hakemli Aile Çocuk ve Ĕ̈itim Dergisi 1/1 (2013) 118-129.

Perry C. P. (2002). "Introducing the Cosmos to the Child". Montessori Life 14/2 (2002) 8-36.

Risinger C. F. (1992). "Trends in K-12 Social Studies". (ERIC Document Reproduction Service No. ED351278). Kaynak: http://www.ericdigests.org/1992-1/k-12.htm

Sabuncu N., Babadă̆ K., Taşocak G. \& Atabek T. (1996). “Hemşirelik Esasları. Ünite 1”. Ed. H. Seçim, Hemşirelik Tanımları, Temel Kavram ve Kuramlar (1996). Eskişehir.

Sánchez X. (2007). “The Hospital Project”. Early Childhood Research and Practice 9/1 (2007) 1-10.

Şahin F., Güven İ. \& Yurdatapan M. (2011). "Proje Tabanlı Eğitim Uygulamalarının Okul Öncesi Çocuklarında Bilimsel Süreç Becerilerinin Gelişimine Etkisi”. M. ̈̈.Atatürk Eğitim Fakültesi, Eğitim Bilimleri Dergisi 33 (2011) 157-176.

Şallı D. (2011). Proje Tabanlı Öğrenme Yaklaşımı ile 48-60 Aylık Çocuklara Geri Dönüşüm Kavramının Kazandırılması. Yayımlanmamış Yüksek Lisans Tezi. Marmara Üniversitesi, İstanbul 2011.

Taylor J. B. (1999). A Child Goes Forth A Curriculum Guide For Prescool Children. New Jersey 1999.

Temel Z. F., Kandır A., Erdemir N. \& Çiftçibaşı K. Ç. (2004). Proje Yaklaşımı ve Program Örnekleri. İstanbul 2004.

Terzioğlu-Çakar, E. (2005). Proje Yaklaşımını Uygulayan ve Uygulamayan Okullara Devam Eden 5-6 Yaş Grubundaki Çocukların Sosyal Gelişim ve Zeka Alanlarının İncelenmesi. Yayımlanmamış Yüksek Lisans Tezi. Hacettepe Üniversitesi, Ankara 2005.

Tuğrul B. \& Güler, T.(2007). “Okul Öncesi Çocuklarına Yönelik Sosyal Çalışma Alanında Tarih ve Coğrafya Eğitimi”. Çukurova Üniversitesi Ĕgitim Fakültesi Dergisi 3/33 (2007) 29-35.

Ünsal F., Yıldız T., Küçükoğlu E. \& Dağal A.(2013). “Dikkat Burası İstanbul!: Okul Öncesinde Aile Katılımlı Proje Tabanlı Bir Program Örneği”. Ĕgitim ve Öğretim Araştırmaları Dergisi 2/2 (2013) 263-270.

Wolk S. (1994). "Project Based Learning: Pursuits with a Purpose”. Educational Leadership 52/3 (1994) $42-45$.

Yıldırım A. \& Şimşek H. (2008). Sosyal Bilimlerde Nitel Araştırma Yöntemleri. Ankara 2008.

Yılmaz F. \& Tekbıyık A. (2013). “Gems Tabanlı Etkinliklerle Desteklenen Proje Yaklaşımının Okul Öncesi Eğitimde Kavramsal Gelişime Etkisi”. Turkish Studies 8/9 (2013) 2375-2399.

Yılmaz H., Beyazkürk D. \& Anlıak Ş. (2011). "Proje Yaklaşımıyla Bir Uygulama Örneği Süt Projesi”. Milli Eğitim Dergisi 172 (2011) 155-174.

Yıldız-Bıçakçı M. \& Gürsoy F. (2010). "Proje Yaklaşımına Dayalı Eğitimin Altı Yaş Çocuklarının Gelişimine Etkisinin İncelenmesi”. Kastamonu Ĕgitim Dergisi 18/1 (2010) 307-316. 